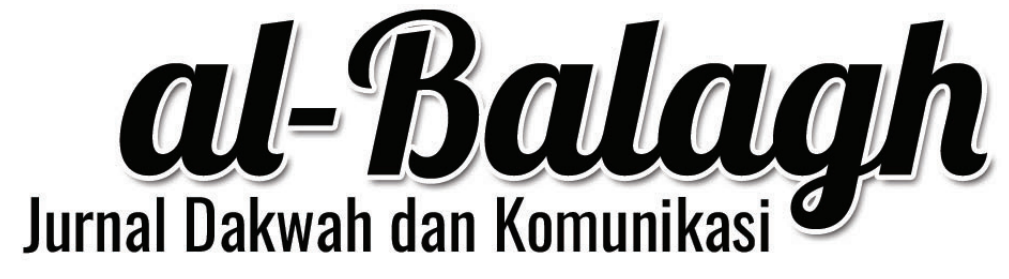




\section{al-Balagh Jurnal Dakwah dan Komunikasi}

ISSN: 2527-5704 (P) ISSN: 2527-5682 (E)

Vol. 3, No. 1, Januari - Juni 2018

\section{Editorial Team}

Editor-In-Chief

Imam Mujahid, IAIN Surakarta

\section{Editorial Board}

Kamaruzzaman bin Yusof, Universiti Teknologi Malaysia Waryono Abdul Ghafur, UIN Sunan Kalijaga, Yogyakarta

Moch. Choirul Arif, UIN Sunan Ampel, Surabaya

Imas Maesaroh, UIN Sunan Ampel, Surabaya

Syakirin Al-Ghazali, IAIN Surakarta

Ahmad Hudaya, IAIN Surakarta

M. Endy Saputro, IAIN Surakarta

\section{Managing Editor}

Akhmad Anwar Dani, IAIN Surakarta

Ahmad Saifuddin, IAIN Surakarta

Rhesa Zuhriya Briyan Pratiwi, IAIN Surakarta

\section{Alamat Redaksi :}

Fakultas Ushuluddin dan Dakwah, IAIN Surakarta

Jl. Pandawa No. 1, Pucangan, Kartasura,

Sukoharjo, Jawa Tengah 57168

Phone : $+62271-781516$

Fax : +62 $271-782774$

Surel : journal.albalagh@gmail.com, journal.albalagh@iain-surakarta.ac.id

Laman : http://ejournal.iainsurakarta.ac.id/al-balagh 


\section{al-Balagh}

ISSN: 2527-5704 (P) ISSN: 2527-5682 (E)

Vol. 3, No. 1, Januari - Juni 2018

\section{Daftar Isi}

Motif Syekhermania Mengakses Video Dakwah

Habib Syech Bin Abdul Qodir Assegafs

Uwes Fatoni dan Eka Octalia Indah Librianti

Pertobatan Wanita Pekerja Seks Komersial (PSK) Di Majelis Asy-Syifa:

Studi Deskriptif Bimbingan Sosio-Spiritual

Titik Rahayu

Analisis Wacana Kritis Berita "Kematian Terduga Teroris Siyono"

Di Harian Solopos

Fathan

Analisis Framing Pesan Kesalehan Sosial pada Buku Ungkapan Hikmah Karya Komaruddin Hidayat

Mubammad Reza Fansuri dan Fatmawati

Syiar Melalui Syair: Eksistensi Kesenian Tradisional Sebagai Media Dakwah Di Era Budaya Populer

Nor Kholis

Peran Masjid dalam Mempersatukan Umat Islam: Studi Kasus

Masjid Al-Fatah, Pucangan, Kartasura

Syakirin 


\title{
PERAN MASJID DALAM MEMPERSATUKAN UMAT ISLAM: STUDI KASUS MASJID AL-FATAH, PUCANGAN, KARTASURA
}

DOI : http://dx.doi.org/10.22515/balagh.v3i1.1092

\author{
Syakirin \\ Institut Agama Islam Negeri Surakarta
}

\section{Keywords: \\ The role of the mosque, the unity of umat}

Kata kunci:

Peran masjid, persatuan umat

\begin{abstract}
Mosque is an instrument of empowerment of people who have a very strategic role in efforts to improve the quality and can unite the community. This article aims to describe the role of the Al-Fatah mosque as a pluralistic and socially pluralistic community empowerment center. The main data comes from interviews and observations, while the method used is qualitative descriptive. This article concludes that the empowerment of the pluralist society around Al-Fatah mosque is done by optimizing the role of all community groups in various mosque activities. The mosque can be the center of activity of all community groups because its activities are not limited to religious activities only, but cover other social social.
\end{abstract}

\begin{abstract}
Abstrak
Masjid merupakan instrumen pemberdayaan umat yang memiliki peran sangat strategis dalam upaya peningkatan kualitas dan bisa mempersatukan masyarakat. Artikel ini bertujuan untuk mendeskripsikan peran masjid Al-Fatah sebagai pusat pemberdayaan masyarakat yang plural baik secara sosial maupun keberagamaan. Data utama bersumber dari wawancara dan observasi, sedangkan metode yang digunakan adalah kualitatif deskriptif. Artikel ini menyimpulkan bahwa pemberdayaan masyarakat pluralis di sekitar masjid Al-Fatah dilakukan dengan optimalisasi peran semua kelompok masyarakat dalam berbagai kegiatan masjid. Masjid dapat menjadi sentra kegiatan semua kelompok masyarakat karena kegiatannya tidak terbatas pada kegiatan keagamaan saja, namun meliputi sosial kemasyarakatan lainnya.
\end{abstract}

Alamat korespondensi:

e-mail: mohsyakirin@yahoo.com 


\section{PENDAHULUAN}

Kelurahan Pucangan merupakan salah satu kelurahan yang ada di Kecamatan Kartasura, Kabupatan Sukoharjo. Oleh karena terletak di ibu kota kecamatan, Pucangan memiliki keistimewaan. Apalagi ketika dilihat dari penduduknya yang notabene sangat strategis, antara lain karena di kelurahan ini terdapat asrama Grup 2 Komando Pasukan Khusus (Kopassus) TNI AD. Di kelurahan Pucangan juga ditempati sebagai lokasi Sekolah Menengah Atas Negeri I (SMA N I) Kartasura, Sekolah Menengah Atas Islam Terpadu (SMAIT) Nur Hidayah, Sekolah Menengah Kejuruan (SMK) Muhammadiyah Kartasura. Selain itu, kelurahan Pucangan juga menjadi lokasi Kampus Institut Agama Islam Negeri (IAIN) Surakarta, yang mempunyai mahasiswa kurang lebih 15.000 orang (Mudofir, 2017) dan ini merupakan potensi yang cukup membanggakan. Keberadaan kampus tersebut akan mempunyai dampak positif bagi masyarakat sekitar. Baik yang menyangkut bidang sosial, ekonomi, budaya maupun keagamaan.

Berdasarkan pantauan peneliti, Pucangan didukung oleh prasarana tempat peribadahan kaum muslimin yang cukup memadai, antara lain masjid Al-Ikhlas yang berlokasi di Rt 01 Rw 01, musholla di komplek SMAN 1 Kartasura, musholla di SMAIT Nur Hidayah, musholla di SMK Muhammadiyah Kartasura, musholla di komplek kantor Desa Pucangan, masjid Daarussalam, komplek Madrasah Diniyah Daarussalam, Gerjen, Pucangan, yang sekaligus juga terdapat pesantren mahasiswa dari berbagai Program Studi yang ada di Institut Agama Islam Negeri (IAIN) Surakarta, Masjid Syamsul Arifin (baru diresmikan pada bulan Ramadhan tahun 2016 M/1437 H) di komplek asrama siswa SMAIT Nur Hidayah Pucangan.

Masjid Al-Fatah yang berlokasi di Rt 02 Rw 01, yang sudah selesai direnovasi, pada mulanya adalah mushola yang sangat sederhana, yang dibangun pada tahun 1985 (Sarjono, 2017). Waktu itu masyarakat yang akan mengikuti salat Jumat harus menuju ke Masjid Keraton Kartasura. Sedangkan, perubahan dari mushola menjadi Masjid al Fatah dan difungsikan untuk salat Jumat adalah pada tahun 1996. Sekarang masjid 
tersebut sudah berubah menjadi dua lantai. Walaupun lokasinya di Rt 02 Rw 01, akan tetapi jamaahnya terdiri dari masyarakat sekitarnya yaitu Rt 12 Rw 3 Kelurahan Kartasura Kecamatan Kartasura, pelajar SMAIT yang menempati rumah penduduk sebagai asrama (tempat tinggal), dan para mahasiswa IAIN yang kost di sekitar masjid. Sebagaimana telah disebutkan bahwa keberadaan asrama Kopassus TNI AD, ini juga berdampak kepada para purnawirawannya yang banyak mengambil tempat tinggal di sekitar asrama, antara lain di RT 02 RW 01.

Masjid merupakan instrumen pemberdayaan umat yang memiliki peran sangat strategis dalam upaya peningkatan kualitas dan bisa mempersatukan masyarakat. Untuk itu, sudah selayaknya jika para dosen dan mahasiswa juga harus terpanggil untuk memanfaatkan masjid guna urun rembug dalam memberdayakan msyarakat sekitarnya, agar kualitas keimanan, keislaman dan keihsanannya bisa lebih ditingkatkan. Hal ini selaras dengan tujuan pembangunan di Indonesia yaitu mensinergikan ke arah kesejehateraan jasmani dan rohani.

Keberadaan masjid al-Fatah, juga merupakan media tempat berkumpulnya para purnawirawan Kopasus dengan masyarakat sekitar. Secara psikologis para purnawirawan adalah golongan masyarakat yang sudah purna tugas, untuk itu golongan ini mempunyai banyak waktu luang. Salah satu kegiatannya adalah arisan warga RT, kerja bakti bersama, dan menghadiri pengajian (Rohani, 2017). Pengajian yang dibina oleh peneliti adalah bertempat di masjid al-Fatah, dengan memanfaatkan waktu setiap hari Selasa malam Rabu sehabis waktu salat Maghrib sampai dengan datangnya waktu Isya. Agenda ini mulai berlaku sejak awal Agustus 2017, sedangkan pada waktu sebelumnya adalah setiap hari Kamis malam Jum'ah.

Salah satu kegiatan rutin yang ada adalah pengajian malam Rabu dengan mengkaji kitab "Riyadussolibin" dibawah asuhan H.M. Syakirin al Ghozali dan kajian tafsir al Qur'an dibawah asuhan Ustaz Yunan Abduh Lc, untuk membina para jamaah masjid al-Fatah. Sebab kebanyakan jamaahnya adalah para bapak dan ibu yang sudah lanjut usia. Dan 
secara psikologis beliau itu sudah banyak merasakan pengalaman hidup dengan kerja keras. Maka sudah saatnya untuk mempersiapkan bekal guna kehidupan di alam akhirat. Dan hal ini sangat terasa sekali, hiruk pikuknya kehidupan yang tidak akan pernah berhenti, sudah saatnya untuk direnungkan kembali. Berbagai kenikmatan yang telah mereka terima dari Zat Yang Maha Mencipta, sudah saatnya untuk disyukuri dengan mulai mencari dan mempelajari ajaran utusan-Nya yaitu Nabi Muhammad SAW yang membawa Islam sebagai agama yang "Rahmatan lil 'Alamin” menjadi rahmat bagi semua penghuni alam.

Usaha ke arah menjadikan masjid sebagai media pendidikan melalui kajian kitab disertai dialog, adalah merupakan suatu sasaran antara, dimana endingnya adalah bagaimana mendampingi masyarakat yang berada di sekitar masjid tersebut menjadi semakin sadar akan jati dirinya, mengapa mereka diciptakan, dan untuk apa mereka hidup serta akan kembali ke mana setelah mereka menjalankan tugasnya sebagai kalifatullah fil ardhi tersebut (Sulthon, 2003). Sulthon (2003) menambahkan bahwa rekayasa sosial merupakan suatu usaha yang berawal dari khairul bariyah terus berproses ke khairul jamaah dan berakhir ke khairul ummah. Untuk itu sungguh sangat tepat apabila kondisi masyarakat yang masih memegang tradisi lokal tersebut juga perlu mendapatkan sentuhan agama agar mereka bisa meningkat menjadi insan yang paripurna.

Berangkat dari fenomena tersebut, maka sangat penting untuk dilakukan penelitian lebih dalam mengenai peran masjid dalam pemberdayaan masyarakat di sekitarnya. Hal ini dinilai penting untuk diteliti karena masjid Al-Fatah dekat dengan IAIN Surakarta dan dekat dengan perumahan pensiunan Kopassus. Mengacu pada rumusan masalah tersebut, maka pertanyaan penelitian adalah: 1) Bagaimana peran masjid Al-Fatah dalam mempersatukan umat Islam di masyarakat sekitarnya?; 2) Upaya dan kegiatan apa sajakah yang dilaksanakan dalam rangka memberdayakan masyarakat di sekitarnya? 
Terdapat beberapa penelitian mengenai revitalisasi masjid, misalkan penelitian Ahmad (2014) mengenai revitalisasi masjid produktif di kota Jambi; Basit (2009) tentang strategi pengembangan masjid bagi generasi muda; Alwi (2015) tentang optimalisasi fungsi masjid dalam pemberdayaan ekonomi masyarakat; Mahmud \& Zamroni (2014) mengenai peran masjid dalam pengembangan pendidikan agama berwawasan multikultural pada masyarakat yang merupakan studi kasus dari Masjid Raya Darussalam dan Masjid Baitul Muttaqien Islamic Center Kalimantan Timur; Dalmeri (2014) mengenai revitalisasi fungsi masjid sebagai pusat ekonomi dan dakwah multikultural; Sutomo (2014) mengenai implementasi nilai religiusitas dan toleransi dalam pemberdayaan masyarakat pada jamaah masjid alhikmah sidomukti Salatiga, Amin (2012) tentang konsep dakwah melalui program posdaya berbasis masjid; Abdzar D (2012) tentang revitalisasi peran masjid sebagai basis media dakwah kontemporer; Zulfa (2015) mengenai transformasi dan pemberdayaan umat berbasis masjid: studi pada masjid Nurussa'adah Salatiga; Sukur (2014) tentang masjid Semarang dalam pertarungan ruang sosial-budaya dan menghasilkan data bahwa masjid di Semarang memiliki banyak kajian Islam yang mengarahkan dan membentuk pemahaman masyarakat; Virga (2016) tentang literasi iklan rokok dan perilaku konsumtif remaja melalui pemberdayaan remaja masjid.

Penelitian ini memiliki pembeda dengan penelitian terdahulu, meskipun temanya adalah mengenai peran masjid dalam bidang keagamaan dan sosial. Pembeda tersebut adalah mengenai tempat, penelitian ini memilih tempat di Pucangan Kartasura dengan pertimbangan heterogenitas masyarakatnya. Sehingga, kondisi ini menjadi bagian yang menarik sekaligus penting untuk diteliti lebih mendalam. Pada akhirnya, akan ditemukan peran masjid dalam mempersatukan umat. 


\section{II.TINJAUAN PUSTAKA}

\section{A. Teori peran}

Peran dalam masyarakat, dapat dijelaskan melalui beberapa cara, yaitu berdasarkan penjelasan historis dan menurut ilmu sosial. Di dalam penjelasan historis, peran berarti karakter yang disandang atau dibawakan oleh seorang aktor dalam sebuah pentas dengan lakon tertentu.Dalam ilmu sosial, peran diartikan sebagai seperangkat tingkah laku yang diiharapkan oleh orang lain terhadap seseorang sesuai kedudukannya dalam suatu sistem. Dari penjelasan diatas, maka dalam penelitian ini peran masjid sangat penting dalam kedudukannya sebagai wadah dalam mempersatukan umat islam.

Sedangkan Menurut Soerjono Soekanto (2009), peran merupakan tindakan atau perilaku yang dilakukan oleh seseorang yang menempati suatu posisi di dalam status sosial, syarat-syarat peran mencangkup tiga hal. Pertama, peran meliputi norma-norma yang dihubungkan dengan posisi atau tempat seseorang dalam masyarakat. Peranan dalam arti ini merupakan rangkaian peraturan-peraturan yang membimbing seseorang dalam kehidupan kemasyarakatan. Kedua, peran mencakup konsep perilaku apa yang dapat dilaksanakan oleh individu-individu dalam masyarakat sebagai organisasi. Peran juga dapat dikatakan sebagai perilaku individu, yang penting bagi struktur sosial masyarakat. Ketiga, peran melibatkan suatu rangkaian yang teratur yang ditimbulkan karena suatu jabatan. Manusia sebagai makhluk sosial memiliki kecenderungan untuk hidup berkelompok. Dalam kehidupan berkelompok tadi akan terjadi interaksi antara anggota masyarakat yang satu dengan anggota masyarakat yang lainnya. Tumbuhnya interaksi diantara mereka ada saling ketergantungan. Dalam kehidupan bermasyarakat itu muncul yang dinamakan peran (role). Peran merupakan aspek yang dinamis dari kedudukan seseorang, apabila seseorang melaksanakan hak-hak dan kewajibannya sesuai dengan kedudukannya maka orang yang bersangkutan menjalankan suatu peranan. 
Berdasarkan beberapa pengertian tersebut dapat ditemukan bahwa peran tidak hanya dilakukan oleh aktor manusia namun juga institusi, dalam hal ini masjid. Sehingga masjid juga mampu memiliki peran yang nyata dalam pemberdayaan masyarakat terutama umat Islam dengan serangkaian kegiatan dakwah yang sesuai dengan Al-Quran dan as-Sunnah. Terutama dalam mempersatukan jamaah masjid walaupun pada mulanya adalah suatu komunitas yang berbeda, akan tetapi dengan usaha yang dilakukan oleh takmir masjid al-Fatah melalui berbagai aktifitas sedikit demi sedikit diharapkan mempunyai dampak positif.

\section{B. Pengertian Masjid}

Kata masjid merupakan isim yang diambil dari kata sujud, bentuk dasarnya adalah sajada - yasjudu. Al-Masjid berarti tempat bersujud. AlMasjad berarti kening orang yang berbekas sujud. Al-Misjad berarti alKhumrah (sajadah), yaitu tikar kecil yang dipakai sebagai alat salat. Sebagian berpendapat bahwa al-Masjid berarti rumah tempat bersujud, sedangkan alMasjad berarti mibrab di rumah-rumah atau tempat-tempat salat diberbagai perkumpulan. Menurut Ibnu al-Arabi, bentuk jamak dari masjid adalah masajid, seharusnya ia tidak mengikuti wazan maf'il, namun menyimpang dari aturan.

Menurut Sibawaih, para ahli bahasa menggolongkan kata al-Masjid sebagai isim yang disandangkan kepada rumah, bukan bentukan dari fi'il berwazan yaf'ilu, Menurut al Fura, kata al-Masjad sama seperti maskan, bentuk dari fi'il berwazan nashara (fa'ala-yaf'ulu), baik sebagai isim maupun masdar (Husain, 2007). Menurut Az-Zujaj, semua tempat ibadah disebut masjid. Bukankah Rasulullah SAW pernah bersanda, "Dan Kujadikan untukku bumi sebagai masjid dan tempat yang suci”.

Sementara itu, Az-Zarkasyi mendefinisikannya sebagai tempat ibadah, seeperti difinisi yang dilontarkan Az-Zujaj, selain itu, ia menduga, pemilihan kata masjid untuk tempat salat adalah karena sujud merupakan perbuatan paling mulia dalam sholat untuk mendekatkan diri kepada Tuhan. 
Senada dengan Az-Zarkasyi,Dr. AbdulMalik As-Sa'di, mendifinisikan masjid sebagai tempat yang khusus disiapkan untuk pelaksanaan sholat lima waktu dan berkumpul, serta berlaku selamanya. Jadi, berdasarkan difinisi ini, tempat yang disediakan untuk salat Eid (baik Idul Fitri maupun Idul Adha) tidak tergolong masjid (Husain, 2007).

\section{Konsep Pemberdayaan Masjid}

Baginda Rasulullah SAW yang datang sebagai orang yang hijrah menuju ke Yatsrib (Madinah al Munawarah) tentunya sudah diinstruksikan oleh Allah SWT antara lain mempersatukan kaum mubajirin dengan kaum anshar. Dua kekuatan ini akhirnya menjadi tonggak yang kuat dalam rangka melajutkan bangunan masyarakat madani yang akhirnya menjadi model. Apalagi ketika piagam Madinah menjadi suatu karya agung dan menjadi pilar peradaban bagi kaum muslimin yang dapat menghargai perbedaan dan multi etnis serta multi kultur di awal pemerintahan Islam di Madinah. Masalah sejarah masjid pertama yang dibangun di Mekah adalah sejak nabi Adam sampai nabi Ibrahim dan Ismail. Hal ini tentunya berdasarkan firman Allah yang menjadikan fungsi masjid sebagai sesuatu yang sangat siginifikan seperti berikut :

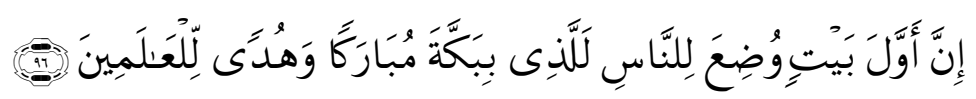

Artinya: Sesungguhnya rumah yang mula-mula dibangun untuk (tempat beribadah) manusia, ialah Baitullah yang di Bakah (Mekah) yang diberkahi dan menjadi petunjuk bagi semua manusia" (Q.S. Ali Imran: 96).

Memang tidak semua orang mempunyai komitmen terhadap tugas sebagai pengurus (takmir) masjid. Akan tetapi, karena motivasi yang diberikan oleh Allah SWT sangat kuat, maka dengan sendirinya untuk menjadi takmir masjid merupakan suatu amanat yang sangat berat tapi sangat mulia, sebagaimana firman Allah SW'T berikut ini: 


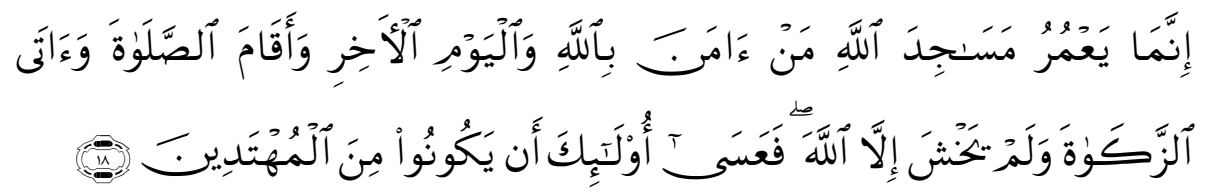

Artinya: Hanyalah yang memakmurkan masjid-masjid Allah ialah orang-orang yang beriman kepada Allah dan hari kemudian serta tetap mendirikan salat, menunaikan zakat dan tidak takut (kepada siapapun) selain kepada Allah, maka merekalah orang-orang yang diharapkan termasuk golongan orang-orang yang mendapat petunjuk"(Q.S. At-Taubah :18)

Begitupun pemberian motivasi kepada kaum muslimin untuk membangun masjid, bagi mereka yang termotivasi akan mendapat pahala sebagaimana yang mereka janjikan disurga kelak, sebagaimana hadis rasul berikut:

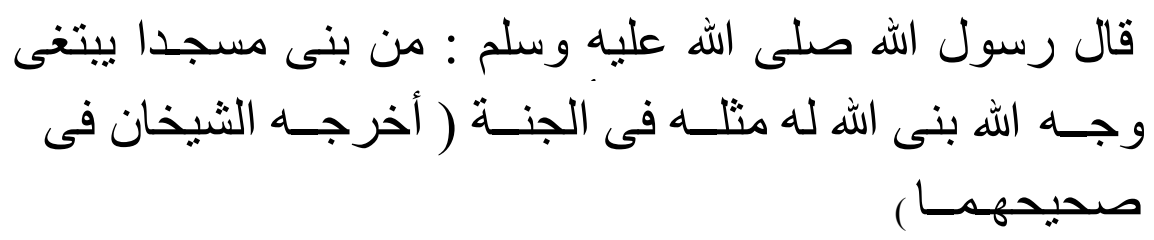

Artinya: Siapa saja orang yang membangun masjid, karena mengharap ridho Allah SWT, maka Allah SWT juga akan membangunkan hal yang sama di syurga (H.R. Bukhari \& Muslim). Berdasarkan dua sumber terpercaya umat Islam tersebut jelas menganjurkan kepada siapa saja umat Islam untuk berusaha agar rumah Allah bisa dibangun di mana saja apabila hal itu memungkinkan.

Sejarah Islam telah mencatat bahwa selama masa 13 tahun Baginda Rasulullah SAW berjuang di Makkah al Mukarramah ditandai dengan berbagai aktivitas yang sangat menantang. Hal ini karena nurani kelompok kafir Quraisy sangat berat untuk menerima cahaya Islam. Berdasarkan kondisi ini, sehingga Allah SWT memerintahkan Rasulnya yang terkasih untuk hijrah ke Yathrib (Madinah al-Munawarab). Pekerjaan pertama dari Rasul dan pengikutnya setiba di Yathrib adalah membangun Masjid Quba. Dari masjid ini Rasul bisa menyatukan kaum Mubajirin (dari Mekah) dengan 
kaum Anshar (penduduk Yathrib). Berawal dari mempersaudarakan kaum muslimin inilah akhirnya menjadi cikal bakal (embrio) satu ummat yang sangat luar biasa kuatnya (baik dari segi fisik maupun mental spiritual).

Dengan berlalunya waktu sampai tiba saatnya untuk membangun masjid di tempat lain (yang sekarang terkenal dengan nama Masjid Nabawi). Di tempat ini berbagai aktivitas dikerjakan oleh Baginda Rasulullah dengan para sahabatnya. Mulai dari men-tadbir/mengatur pemerintahan, menyelesaikan perselisihan paham, majelis ilmu, menerima tamu dari kabilah lainnya, latihan perang, sampai kepada merawat para mujahidin yang luka dalam jihad fisabilillah. Ala kulli hal semua aktivitas tentang kehidupan tidak lepas dari semangat ruh masjid (dalam arti semangat keislaman) (Mahmud, 1976; Gazalba \& Masyhar, 1971). Hasilnya, kejayaan Islam bisa disebarkan ke pelbagai penjuru negara antara lain bisa sampai ke Asia Tenggara yang di dalamnya ada negara Indonesia.

Seperti yang sudah disampaikan bahwa masjid sangat banyak fungsinya sebagaimana yang telah dicontohkan Baginda Rasulullah SAW. Umat Islam di Indonesia juga telah banyak membangun masjid/mushala. Misalkan, di kampung-kampung yang banyak masyarakat muslimnya, atau dimana saja yang ada ummat Islamnya baik itu di pabrik- pabrik, pasarpasar, perkantoran, lembaga pendidikan dan tempat- tempat fasilitas umum seperti rumah sakit, tempat pemberhentian alat transportasi: seperti air port, pelabuhan kapal laut, terminal bus, stasiun kereta api, gedung-gedung pertemuan umum dan lainnya. Hal ini jelas sangat menggembirakan walaupun aktivitasnya masih terbatas karena kurangnya pentadbir/manajer.

Bahkan langkah awal yang disarankan oleh Yusuf al-Qardhawi (2000) antara lain disamping masalah tempat yang strategis, adalah meluruskan niat. Dalam hal ini orang yang akan membangun masjid adalah sematamata untuk mencapai keridhaan Allah SWT. Selanjutnya agar masjid tersebut menjadi tempat kaum muslimin, baik untuk melaksanakan salat lima waktu, berzikir, majelis taklim, mensyiarkan agama Islam, dan hal lainnya yang positif. 
Sehingga, multifungsi dari masjid ini dapat diupayakan bersama dengan masyarakat sekitar (Supardi \& Amiruddin, 2001), terlebih lokasi masjid Al-Fatah yang dekat dengan kampus IAIN Surakarta. Kondisi ini menyebabkan adanya akulturasi antara masyarakat umum, mahasiswa, pensiunan tentara, dan sebagainya. Hal inilah yang akan peneliti kaji dalam penelitian ini. Terlebih lagi, ajaran Islam memang mengajarkan mengenai cara dan contoh yang telah diajarkan oleh Baginda Rasulullah SAW dalam menyatukan dan memberdayakan umat muslim sebagaimana yang terjadi di kota Madinah al-Munawarah (Khaeruman, 2005).

Untuk mengaplikasikan teori tentang fungsi masjid dalam memberdayakan ummat sekitarnya, maka sangat ideal apabila Lembaga Penelitian dan Pengabdian kepada Masyarakat Institut Agama Islam Negeri (LP2M IAIN) Surakarta menugaskan para dosen untuk membimbing para mahasiswanya dalam program Kuliah Kerja Nyata Terpadu Berbasis Masjid (KKNT-BM) tahun 2017. Pada tahun 2017 ini juga diberi kesempatan kepada para mahasiswa untuk melakukan KKNTBM secara mandiri, secara khusus dan secara reguler. Dimana dalam hal ini ada yang melaksanakan di luar daerah seperti di Propinsi Bali, Lombok Nusa Tenggara Barat, Bandar Lampung, Kabupaten Wonogiri, Kabupaten Boyolali, dan Kabupaten Sukoharjo sendiri (LP2M IAIN Surakarta, 2017).

Dalam hal pembangunan masyarakat, Mohammad Fazlurrahman Anshari memberikan gagasannya bahwa untuk menuju masyarakat Islam modern diperlukan tuntunan yang jelas, yaitu al Qur'an dan Assunnah Rasulullah SAW. Selain itu, juga harus mengedepan pemahaman "theocentris dan ethic-religius" yang dilestarikan dalam upaya kebajikan. Sebagai masyarakat muslim modern, maka falsafah sosialnya didasarkan pada sistem nilai yang paling tinggi dan paling penting, karena mengimani dan menyembah Allah SWT. Untuk itu harapannya, masyarakat tersebut bisa mengaplikasikan dalam berbagai bidang seperti berlaku adil, memelihara keindahan dan kebersihan, kasih sayang serta pelayanan dan memuaskan terhadap sesama (Anshari, 1984). 


\section{METODE PENELITIAN}

Penelitian ini menggunakan metode kualitatif deskriptif yang bertujuan untuk menganalisis fenomena empirik berdasarkan kondisi yang terjadi secara alamiah. Creswell (2010) menyebutkan bahwa penelitian deskriptif kualitatif tidak bermaksud untuk menguji hipotesis tertentu, tetapi hanya mengemukakan apa adanya tentang variabel, gejala atau keadaan. Melalui pendekatan kualitatif, peneliti akan melihat mengenai fenomena yang diangkat dalam penelitian ini. Kemudian, dijelaskan secara komprehensif dan juga berpengaruh kepada perubahan yang akan terjadi. Pada dasarnya, penelitian ini akan melihat secara objektif dari penelitian sebelumnya dan juga memandang penelitian yang akan dilaksanakan. Pemilihan deskriptif analisis adalah sebuah teknik pengkajian yang dilakukan dengan cara menganalisa beberapa parameter yang dipandang determinan bagi sebuah topik yang dipelajari.

Tempat penelitian ini bernama Masjid al-Fatah, yang beralamat di Jalan Turonggono, RT 02/01, Kelurahan Pucangan, Kecamatan Kartasura, Kabupaten Sukoharjo, Jawa Tengah, Indonesia. Masjid ini merupakan wakaf dari keluarga bapak Drs. H. Yusuf Sunarto, kepada perserikatan Muhammadiyah. Walaupun begitu, sewaktu peresmiannya dijelaskan bahwa pemanfaatan bangunan masjid tersebut adalah untuk umum, sebab yang ikut membantu pembangunannya adalah masyarakat umum, baik yang ada di sekitar masjid maupun dari tempat lainnya.

Untuk mendukung penelitian ini sumber data diperoleh dari beragam sumber (multiple source data) baik yang didapat secara langsung maupun tidak langsung. Data yang diperoleh secara langsung adalah melalui wawancara antara lain dengan Pengurus Masjid (Takmir Masjid al Fatah), dengan keluarga pewakaf karena bapak Drs. Yusuf Sunarto, sudah meninggal dunia pada tanggal 20 Agustus 2017; dengan perwakilan jamaah masjid alFatah yang dianggap representatif dan banyak mengetahui tentang sejarah pembangunan masjid sejak awal samapai akhir; dengan para pengelola dan 
pengajar TPA, karena mereka yang menjalankan langsung program dari takmir masjid.

Selanjutnya dengan menggunakan observasi partisipan di masjid Al-Fatah, Pucangan. Hal ini dilakukan untuk menggali dan memperoleh informasi terkait permasalahan yang diangkat dalam penelitian. Sedangkan sumber data tidak langsung yang didapat melalui kajian kepustakaan melalui buku, jurnal, artikel maupun publikasi lainnya yang memiliki keterkaitan dengan penelitian ini.

Herdiansyah (2013) menjelaskan bahwa untuk data primer menggunakan wawancara, observasi dan bila diperlukan dilakukan focus group discussion. Untuk data sekunder dengan studi pustaka dan pengambilan dokumen pendukung lainnya yang relevan dengan penelitian. Dalam hal ini karena peneliti juga sebagai pengurus takmir masjid al-Fatah, maka secara otomatis sering diajak rapat apabila akan menyelenggarakan aktifitas masjid seperti menjelang datangnya bulan Ramadhan, mempersiapkan panitia qurban, dan lainnya.

Menurut Moleong (2001), keabsahan data merupakan konsep penting yang diperbaharui dari konsep kesahihan (validitas) dan keandalan (reliabilitas) yang harus disesuaikan berdasarkan tuntunan pengetaahuan, kriteria dan paradigma sendiri. Teknik untuk pemeriksaan data pada penelitian ini menggunakan Triangulasi, yang dimaksud adalah teknik pemeriksaan keabsahan data yang memanfaatkan sesuatu yang lain diluar data untuk keperluan pengecekan dan sebagai pembanding terhadap data tersebut. Triangulasi ada beberapa diantaranya: sumber, penyidik, teori dan metode yang digunakan dalam penelitian ini, adalah menggunakan triangulasi sumber.

Cara yang dilakukan dalam pengolahan atau analisis data kualitatif adalah menggunakan data yang diperoleh, mengorganisasikan dan memilah-milah data menjadi satuan yang dapat dikelola, menyintesiskan, mencari dan menemukan pola, menemukan sesuatu yang dapat diceritakan kepada orang lain. Menurut Glasser dan Straus, dalam penelitian kualitatif 
analisis data dilakukan terus-menerus sepanjang penelitian atau yang sering disebut dengan constant comparative method. Hal ini menjelaskan bahwa analisis data bukan sesuatu yang bersifat inklusif yang dapat ditegaskan waktu terjadinya pada satu waktu tertentu selama proses penelitian.

\section{HASIL PENELITIAN DAN PEMBAHASAN}

Lokasi penelitian ini adalah Masjid al-Fatah yang sebelumnya masih berupa mushola al-Fatah yang mulai berdiri pada tahun 1985, dan berubah menjadi masjid untuk menyelenggarakan salat Jum'ah pada tahun 1997, berada di Jalan Turonggono, Rt 02 Rw 01 Kelurahan Pucangan Kecamatan Kartasura, Kabupaten Sukoharjo.

Kondisi masyarakat asli dukuh Pucangan Desa Pucangan ini sangat sederhana, maka dalam membangun rumah ibadah bagi kaum musliminpun sangat sederhana. Yaitu masjid yang berukuran 13 x $15 \mathrm{M}^{2}$ Dengan kondisi lantainya dengan plester dan dengan dinding tembok. Dilengkapi tempat wudhu juga dengan sederhana untuk kaum laki-laki dan perempuan. Bangunan masjid tersebut juga hanya terdiri dari satu lantai.

Kondisi bangunan tersebut dibagi menjadi ruang utama untuk sholat dan ruang sayap kanan dan kiri untuk menampung jamaah kaum perempuan disebelah kanan. Sedangkan yang sebelah kiri dipakai kaum laki-laki apabila jamaah didalam ruang utama sudah penuh..Kondisi semacam ini berlangsung cukup lama. Walaupun pada tahun delapan puluhan sudah mulai ada jamaah yang terdiri dari para purnawiraan dari Korps Pasukan Khusus TNI Angkatan Darat dari Grup Dua Kandang Menjangan Kartasura, yang membangun rumah disekitar Masjid al Fatah.Sampai akhirnya ada keputusan dari Kementrian Agama RI untuk membangun kampus IAIN Walisongo di Surakarta, di Desa Pucangan Kecamatan Kartasura Kabupaten Sukoharjo.

Walaupun dalam kesederhanaan, masjid ini sangat strategis sebab terletak di pinggir jalan yang menuju kampus IAIN Surakarta. Selain itu, jalan tersebut juga menghubungkan antara jalan pasar Kartasura menuju 
kawasan SMK Muhammadiyah Kartasura serta ke kelurahan Ngemplak Kartasuro bahkan bisa juga menuju ke Stasiun Gawok Kecamatan Gatak Kabupaten Sukoharjo.

Beberapa mahasiswa IAIN Surakarta ada yang menunggu mata kuliah berikutnya di masjid al-Fatah jika waktu selangnya cukup lama. Selain itu, sambil menunggu waktu mata kuliah selanjutnya, mereka juga menunggu waktu Zuhur. Apalagi fasilitas air dan kipas angin yang membuat suasana masjid menjadi kondusif untuk salat ataupun untuk membaca mengulangi pelajaran yang mereka terima di bangku kuliah. Atau bisa juga sambil mengulangi hafalan Alquran yang mereka pelajari atau hafalan hadis yang mereka terima dari para dosen masing-masing. Sebagai tanggung jawab pengelolaan masjid maka disusun struktur takmir masjid yang terdiri dari:

A. Penasehat : Bp. Drs. H. Yusuf Sunarto

Bp. Dr. H. M. Syakirin Al Ghozali, MA.

Bp. Drs. H. Wahyudi, M.Pd.

Bp. H. Sugiarto

Bp. drg. Edi Karyadi, MM.

B. Ketua 1 : Bp. dr. M. Shoim Dasuki, M.Kes.

Ketua 2 : Bp. M. Ari Sarjono, S.Far.,Apt.

Jajaran pimpinan dibantu juga oleh sekretaris, bendahara, amaliah ibadah harian, seksi keamanan, kajian dan pendidikan, seksi keputrian, pengembangan sarana dan prasarana; dan seksi pemuda.

Dengan terbentuknya kepengurusan takmir masjid al Fatah, maka secara otomatis kegiatannnya akan lebih tertib, baik yang menyangkut kegiatan rutin maupun kegiatan yang bersifat insidental. Hal ini sesuai dengan pembicaraan di antara para jamaah masjid agar ke depannya semakin makmur dan berdaya guna dalam pemberdayaan bagi masyarakat sekitar. Untuk mendukung tercapainya pendayagunaan tersebut, diadakan musyawarah untuk mengisi kegiatan sesuai dengan kondisi yang ada.

Pertama, kegiatan ibadah salat berjamaah lima waktu dalam sehari semalam, maka disusunlah Imam salat rawatib yang rutin. Selain itu, juga 
dilakukan penjadwalan khatib dan imam salat Jumat menurut weton Jawa (Jum'at Pon, Kliwon, Pahing, Wage dan Legi).

Kedua, kegiatan TPA al-Fatah dilaksanakan untuk mendidik dan mempersiapkan para kader dari warga masyarakat sekitar masjid al-Fatah, maka pengurus menugaskan kepada para ustaz/ah. Kegiatan TPA yang diselenggarakan oleh Masjid al-Fatah diadakan tiga kali dalam sepekan, yaitu setiap hari Selasa, Jumat dan Ahad dari jam 15.30 WIB - 17.00 WIB. Para pesertanya adalah dari siswa/i SD dari para masyarakat sekitar masjid al-Fatah.

Ketiga, kegiatan bulan Ramadhan tahun 2017 Masegi/ 1438 Hijriyah antara lain mengadakan pawai menyambut bulan Ramadhan dengan berkeliling kampung sambil membawa tulisan yang beraneka ragam yang isinya mengingatkan kepada semua bahwa sebentar lagi akan datang bulan Ramadhan. Tulisan tersebut merupakan dorongan masyarakat agar bisa mengisinya dengan berbagai kebaikan yang berdampak positif untuk pembangunan masyarakat yang berkeadaban. Selain bulan Ramadhan sebagai waktu latihan puasa "mbedhuk" (Tradisi latihan puasa bagi anakanak yang belum mampu puasa sehari penuh, mereka dilatih puasa sampai waktu zuhur. Mereka bisa berbuka pada waktu zuhur untuk selanjutnya boleh meneruskan puasanya sampai waktu maghrib).

Keempat, masjid al-Fatah juga menyelenggarakan kegiatan pada bulan Ramadhan antara lain dengan buka bersama dengan masyarakat sekitar setiap hari Ahad sore yang disponsori oleh beberapa keluarga/ warga masyarakat secara bergantian. Selain itu, setiap sore bagi anakanak (satriwan/wati) TPQ akan mendapatkan takjilan yang berupa snack (jajanan/makanan nasi bungkus yang disponsori secara bergantian dari masyarakat sekitar). Sedangkan khusus hari Ahad mereka juga ikut bergabung dengan masyarakat untuk mendengarkan pengajian untuk memperkuat keimanan para jamaah masjid dan keluarga. Sedangkan yang mengisi pengajiannya antara lain oleh Ketua Takmir masjid sendiri yaitu bapak dr. M. Shoim Dasuki. M.Kes (dosen Fakultas Kedokteran UMS). 
Selain itu juga ada H. M. Syakirin al Ghozali, Ph.D (dosen Fakultas Ushuluddin dan Dakwah IAIN Surakarta). Selanjutnya juga diisi oleh Prof. Dr. Bambang Sumarjoko (Guru Besar UMS) dan drg. Edi Kariadi MM, dosen Fakultas Kedokteran Gigi UMS). Untuk memberikan motivasi bagi para peserta didik atau santriwan/wati selama bulan Ramadhan, para ustaz/zah mengadakan lomba. Hal ini sebagai salah satu bentuk evaluasi terhadap kegiatan belajar mengajar selama bulan Ramadhan.

Kelima, kegiatan Penyembelihan hewan kurban pada tahun 2017 Masehi/1438 Hijriyah. Setiap tahun takmir masjid al-Fatah menyelenggarakan kegiatan penyembelihan hewan qurban dari para jamaah masjid untuk dibagikan kepada masyarakat sekitar masjid. Dalam hal ini para pekorban dan panitia serta masyarakat sekitar dengan bersama-sama mengerjakan penyembelihan, pengulitan, pencacahan, dan pembagian sesuai dengan kebijakan yang diterapkan oleh panitia. Semua masyarakat yang sudah didaftar oleh panitia akan mendapatkan bagian. Sehingga kebersamaan dan kepedulian sesama jamaah masjid dan masyarakat sekitarnya menjadi semakin akrab.

\section{PEMBAHASAN}

Untuk membangun masjid al-Fatah yang awalnya memiliki luas 13 meter $^{2}$ kali 15 meter $^{2}$ menjadi 15 meter $^{2}$ kali 17 meter $^{2}$, tentunya membutuhkan dana yang tidak sedikit. Oleh karena itu, sumbangan dari berbagai pihak yang sampai kepada panitia pembangunan masjid al Fatah, merupakan bukti bahwa para jamaah dan masyarakat sekitar sangat peduli terhadap adanya pembangunan tersebut. Hal ini menunjukkan bahwa tingkat kepedulian juga termasuk salah satu media pemersatu ummat.

Dari komposisi kepengurusan takmir masjid al-Fatah, Rt 02/01 Kelurahan Pucangan Kecamatan Kartasura Kabupaten Sukoharjo, Jawa Tengah, menunjukkan bahwa susunan pengurusnya mencerminkan keanekaragaman. Ada yang mewakili masyarakat setempat, ada yang mewakili kaum muhajirin (pendatang baru). Para pendatang baru ini 
misalkan dari latar belakang mantan Kopasus TNI AD, ada yang dari komunitas akademisi, dan para mahasiswa serta siswa/i dari sekolah yang ada di sekitar masjid al-Fatah.

Begitupun dari komposisi para pengajar/ustaz/zah TPQ al Fatah, maka dapat dilihat bahwa para mahasiswa yang tinggal di sekitar masjid al-Fatah, ikut terpanggil untuk memberikan andilnya terutama dalam rangka ikut mencerdaskan anak bangsa, melalui jalur pendidikan yang diselenggarakan oleh masjid al-Fatah. Ini juga merupakan simbol kebersamaan dalam rangka memelihara dan merawat budaya adiluhung. Telah disebutkan bahwa ciri-ciri orang yang berbudaya adalah mereka yang peduli kepada sesama, terutama kepada generasi penerus yang memerlukan uluran keilmuan yang sudah dimiliki. Jadi secara tidak langsung ini juga memberikan informasi bahwa kebersamaan dan tanggung jawab merupakan sifat yang diajarkan oleh ajaran Islam.

Komposisi imam salat rawatib juga sangat variatif. Kondisi ini ditunjukkan dalam bentuk imam salat rawatib ditunjuk berdasarkan keterwakilan dari berbagai kesempatan. Hal ini bukan berarti mengesampingkan persyaratan seseorang untuk menjadi imam salat rawatib. Akan tetap, inovasi dari pengurus takmir masjid untuk mengakomodasi seluruh komunitas yang berada dalam agama Islam. Begitupun para khatib salat Jumat, juga menunjukan keanekaragaman.

\section{KESIMPULAN}

Penelitian ini dilakukan untuk melihat peran masjid dalam suatu komunitas di daerah yang posisinya terletak di dekat dengan instalasi militer, kampus, dan masyarakat yang sangat heterogen. Beberapa kesimpulan yang dapat dikemukakan antara lain sebagai berikut : Pertama, masjid merupakan suatu tempat yang sangat dimuliakan oleh umat Islam dimanapun berada. Untuk itu keberadaannya sangat memberikan suasana yang sangat istimewa, sebagaimana yang pernah dicontohkan oleh baginda Rasululllah SAW ketika di Madinah al-Munawarah. 
Kedua, masjid al-Fatah di Rt 02/01 Kelurahan Pucangan, Kecamatan Kartasura, Kabupaten Sukoharjo, Jawa Tengah, memiliki beberapa peran dan fungsi. Misalkan, fungsi untuk pendidikan, konsolidasi sosial keumatan melalui aktifitas kajian yang diselenggarakan setiap hari Selasa dan setiap hari Kamis. Agenda ini adalah bukti bahwa masjid sebagai lembaga keagamaan sudah berfungsi dengan baik.

Ketiga, pemberian peran dari berbagai latar belakang komunitas yang ada di masyarakat untuk memakmurkan masjid al-Fatah. Sebab dengan keikutsertaan semua komponen yang ada di masyarakat, maka secara tidak langsung akan mengurangi ketegangan, dan sekaligus akan memperkuat persatuan umat.

Keempat, Taman Pendidikan Qur'an (TPQ) yang diselenggarakan oleh masjid al-Fatah adalah suatu ikhtiar dari takmir agar regenerasi kaum muslimin bisa berjalan dengan lancer. Dengan demikian, tidak ada kesenjangan karena sejak dini mereka selalu akrab dengan masjid sebagai pusat kegiatan yang sangat positif. Hal ini sekaligus juga menanamkan jiwa ukhuwah Islamiyah sejak dini, sehingga ketika mereka sudah menginjak usia remaja dan menjadi dewasa mereka sudah saling kenal dan akrab yang dimulai dari masjid sebagai simbol persatuan umat Islam.

\section{DAFTAR PUSTAKA}

Abdzar D, M. (2012). Revitalisasi Peran Masjid Sebagai Basis Media Dakwah Kontemporer. Jurnal Dakwah Tabligh, Vol. 13, No. 1, Juni 2012, 109 - 121.

Ahmad, H. (2014). Revitalisasi Masjid Produktiif. TAJDID Vol. XII, No. 2, Juli-Desember 2014, 365-392.

al- Qaradhawi, Y. (2000). Al Dhawabit al Syar'iyah Libinai al Masajid (Tuntunan Membangun Masjid). Jakarta: Gema Insani Press.

Alwi, M. M. (2015). Optimalisasi Fungsi Masjid Dalam Pemberdayaan Ekonomi Masyarakat. Al-Tatwir, Vol. 2, No. 1 Oktober 2015, 113152.

Amin, M. (2012). Konsep Dakwah Melalui Program Posdaya Berbasis 
Masjid. Jurnal Dakwah Tabligh, Vol. 13, No. 1, Juni 2012, 97 - 108. Anshari, F. (1984). Konsepsi Masyarakat Islam Modern. Bandung: Arrisalah. Basit, A. (2009). Strategi Pengembangan Masjid Bagi Generasi Muda. KOMUNIKA Vol. 3, No. 2, Juli-Desember 2009, 270-286.

Creswell, J. W. (2010). Research Design: Pendekatan Kualitatif, Kuantitatif, dan Mixed. Yogyakarta: Pustaka Pelajar.

Dalmeri. (2014). Revitalisasi Fungsi Masjid Sebagai Pusat Ekonomi Dan Dakwah Multikultural. Walisanga, Vol. 22, No. 2, November 2014, 321-350.

Gazalba, S., \& Masyhar, M. A. (1971). Masjid Pusat Pembinaan Ummat. Jakarta: Pustaka Antara.

Herdiansyah, H. (2013). Wawancara, Observasi dan Focus Group: Sebagai Instrumen Penggalian Data Kualitatif. Jakarta: Rajawali Press.

Husain, H. Y. (2007). Fikih Masjid. Jakarta: Al-Kautsar.

Khaeruman, B. (2005). Islam dan Pemberdayaan Umat. Bandung: Pustaka Setia.

LP2M IAIN Surakarta. (2017). Panduan Kuliah Kerja Nyata Transformatif Berbasis Masjid. Surakarta: IAIN Surakarta.

Mahmud, A. A. (1976). Al Masjid Wa Atsarubu Fi Al Mujtama' al Islami. Kahira: Dar al-Ma' arif.

Mahmud, M. E., \& Zamroni. (2014). Peran Masjid Dalam Pengembangan Pendidikan Agama Berwawasan Multikultural Pada Masyarakat (Studi Multi Situs Di Masjid Raya Darussalam, Masjid Baitul Muttaqien Islamic Center Kalimantan Timur). FENOMENA, Vol. 6, No. 1, 2014, 155-170.

Moleong, L. J. (2001). Metodologi Penelitian Kualitatif. Bandung: Remaja Rosdakarya.

Mudofir. (2017, Juli 24). Sambutan Rektor IAIN Surakarta pada acara Rapat Pleno Senat Institut di Ruang Rapat Senat IAIN Surakarta. (S. Al-Ghozali, Interviewer)

Rohani. (2017, Agustus 18). Wawancara Kepada Mantan Koppasus Yang Menjadi Imam Masjid. (S. Al-Ghozali, Interviewer)

Sarjono, A. (2017, Agustus 25). Wawancara Sejarah Masjid. (S. Al-Ghozali, Interviewer)

Soekanto, S. (2009). Sosiologi Suatu Pengantar. Jakarta: Rajawali Press. 
Sukur, F. (2014). Masjid Semarang Dalam Pertarungan Ruang SosialBudaya. Ibda', Jurnal Kebudayaan Islam, Vol. 12, No. 1, Januari-Juni 2014, 40-49.

Sulthon, M. (2003). Desain Ilmu Dakwah. Yogyakarta: Pustaka Pelajar.

Supardi, \& Amiruddin, T. (2001). Manajemen Masjid dalam Pembangunan Masyarakat. Yogyakarta: UII Press.

Sutomo, I. (2014). Implementasi Nilai Religiusitas Dan Toleransi Dalam Pemberdayaan Masyarakat Pada Jamaah Masjid Al-Hikmah Sidomukti Salatiga. INFERESI, Jurnal Penelitian Sosial Keagamaan, Vol. 8, No. 1, Juni 2014, 93-114.

Virga, R. L. (2016). Literasi Iklan Rokok Dan Perilaku Konsumtif Remaja Melalui Pemberdayaan Remaja Masjid. Profetik Jurnal Komunikasi, Vol. 9, No. 2, Oktober 2016, 33-44.

Zulfa, M. (2015). Transformasi Dan Pemberdayaan Umat Berbasis Masjid: Studi Pada Masjid Nurussa'adah Salatiga. INFERENSI, Jurnal Penelitian Sosial Keagamaan, Vol. 9, No. 1, Juni 2015, 257-278. 